\title{
Recapitulating aspects of the oxygen and substrate environment of the damaged joint milieu for stem cell based cartilage tissue engineering
}

\author{
${ }^{+}$O hEireamhoin, S. ${ }^{1}$; ${ }^{+}$Buckley, C. T. ${ }^{1,2}$; Jones, E. ${ }^{3}$; McGonagle, D. ${ }^{3}$; Mulhall, K. J. ${ }^{1,4}$; \\ Kelly, D. J*1,2.
}

1. Trinity Centre for Bioengineering, Trinity Biomedical Sciences Institute, Trinity College Dublin, Ireland.

2. Department of Mechanical and Manufacturing Engineering, School of Engineering, Trinity College Dublin, Ireland.

3. NIHR Leeds Biomedical Research Unit, Leeds Institute of Molecular Medicine, University of Leeds, United Kingdom.

4. Sports Surgery Clinic, Dublin, Ireland.

${ }^{+}$Both authors contributed equally to this study.

*Corresponding author: Daniel J. Kelly

E-mail address: kellyd9@tcd.ie

Address: Trinity Centre for Bioengineering

Trinity Biomedical Sciences Institute

Trinity College Dublin

Ireland

Telephone: +353-1-896-3947

Fax: +353-1-679-5554

Short Title: Chondrogenesis of human infrapatellar fat pad stem cells

Keywords: Cartilage, Stem Cell, Infrapatellar Fat Pad, Oxygen, Fibroblast Growth Factor2, Chondrogenesis, Fibrin, Agarose. 
Abstract

Human infrapatellar fat pad (IFP) contains a source of mesenchymal stem cells (FPSCs) which potentially offer a novel population for the treatment of damaged or diseased articular cartilage. Existing cartilage repair strategies such as microfracture harness the presence of a low oxygen microenvironment, fibrin clot formation at sites of microfracture and elevations in growth factors in the damaged joint milieu. Bearing this in mind, the objective of this study was to determine the chondrogenic potential of diseased human FPSCs in a model system that recapitulates some of these features. In the first phase of the study, the role of transforming growth factor beta-3 (TGF- $\beta 3$ ) and fibroblast growth factor-2 (FGF-2), in addition to an altered oxygen tension environment, on the colony-forming unit-fibroblast (CFU-F) capacity and growth kinetics of human FPSCs during monolayer expansion was evaluated. The subsequent chondrogenic capacity of these cells was quantified in both normoxic (20\%) and low (5\%) oxygen conditions. Expansion in FGF-2 was shown to reduce CFU-F numbers but simultaneously increase both colony size and cell yield compared to standard expansion conditions. Supplementation with both FGF-2 and TGF- $\beta 3$ significantly reduced cell doubling time. Expansion in FGF-2, followed by differentiation at 5\% oxygen tension, was observed to synergistically enhance subsequent sGAG accumulation following chondrogenic induction. FPSCs expanded in FGF-2 were then encapsulated in either agarose or fibrin hydrogels in an attempt to engineer cartilaginous grafts. sGAG synthesis was higher in fibrin constructs, and was further enhanced by differentiation at 5\% oxygen tension, accumulating $2.7 \%$ (ww) sGAG following 42 days in culture. These results indicate that FPSCs, a readily accessible cell population, forms cartilage in an in vitro environment that recapitulates several key biological features of cartilage repair during microfracture and also points towards the potential utility of such cells when combined with fibrin hydrogel scaffolds. 


\section{Introduction}

Human infrapatellar fat pad (IFP) contains mesenchymal stem cells (MSCs) which can be easily harvested arthroscopically ${ }^{1}$ and which have the ability to differentiate into chondrocyte-, osteoblast-, or adipocyte-like cells under appropriate culture conditions ${ }^{2}$. Stem cells isolated from osteoarthritic fat pads have been shown to be highly clonogenic and have demonstrated at least comparable chondrogenesis to cells isolated from adult articular cartilage $^{3}$. These findings have motivated increased interest in using this cell source for cartilage tissue engineering and other cell based therapies for articular cartilage repair ${ }^{4-8}$. Intra-articular injection of IFP derived mesenchymal stem cells (FPSCs) has been shown to reduce cartilage degeneration in an experimental rabbit model of osteoarthritis ${ }^{9}$, while the mechanical properties of cartilaginous tissues engineered using this cell source have been shown to improve with time in culture ${ }^{5,10-11}$ and express key proteins important for functional cartilage repair such as superficial zone protein/lubricin ${ }^{12-13}$.

Therapeutic tissue engineering applications require the reliable production of relatively large numbers of donor-specific cells ${ }^{14}$, therefore the identification of MSC expansion conditions that accelerate proliferation while maintaining multipotency is important for clinical applications. Supplementation of expansion media with various growth factors has been explored in an attempt to improve the isolation and expansion of progenitor cells isolated from different tissues ${ }^{15-18}$. For example, fibroblast growth factor-2 (FGF-2) has been shown to enhance the proliferation of bone marrow ${ }^{14,19-22}$, adipose ${ }^{23}$, periosteum ${ }^{24}$ and IFP $^{25-26}$ derived MSCs and to delay the loss of chondrogenic potential in bone marrow derived MSCs with passaging ${ }^{27}$. In the case of FPSCs, expansion in the presence of FGF-2 has also been shown to enhance their subsequent chondrogenic potential ${ }^{25}$. Various subtypes of transforming growth factor beta (TGF- $\beta$ ) have also been added to expansion media in order to enhance proliferation and subsequent chondrogenesis of chondrocytes and $\mathrm{MSCs}^{16 \text {, }}$ 
${ }^{28-30}$. Of note is the finding that chondrocytes expanded with FGF-2 and TGF $\beta 1$ displayed the lowest doubling times during expansion and subsequently generate cartilaginous tissues with the highest accumulation of glycosaminoglycans and collagen type $\mathrm{II}^{31}$. The in vitro the maturation of cartilage tissue is also enhanced using a similar combination of growth factors $^{32}$.

Oxygen tension has also been shown to regulate MSC proliferation and differentiation ${ }^{33}$. Expansion of MSCs at a low oxygen tension has been shown to increase cell yield and reduce doubling times ${ }^{34-37}$, as well as promoting the chondrogenic potential of cells isolated from bone marrow ${ }^{38-40}$, adipose tissue ${ }^{41}$ and cartilage ${ }^{42-43}$. Furthermore, enhanced chondrogenesis has been reported for MSCs undergoing differentiation at low oxygen tensions ${ }^{39,}{ }^{44-48}$, although there are also reports of hypoxic conditions inhibiting chondrogenesis ${ }^{49-50}$. For IFP derived MSCs, chondrogenic differentiation at 5\% oxygen has been shown to increase expression of hypoxia-inducible transcription factor (HIF) $2 \alpha$, reduce cell proliferation and enhance matrix synthesis ${ }^{51}$. The functional properties of cartilaginous tissues engineered using IFP derived MSCs are also improved in a low oxygen environment ${ }^{52}$

Clearly the proliferation and differentiation capacities of MSCs isolated from multiple tissue types are strongly dependent on the local environment, however the expansion and differentiation conditions required to engineer truly functional cartilaginous grafts using human MSCs remain to be elucidated. Spontaneous regenerative events in the body may provide clues as to how we should engineer such tissues. Specifically, existing cartilage repair strategies such as microfracture, although imperfect, harness the presence of a low oxygen microenvironment ${ }^{53}$, fibrin deposition at sites of microfracture ${ }^{54}$ and elevations in growth factors ${ }^{55}$ in the damaged joint environment to induce both the proliferation and differentiation of MSCs. Bearing this in mind, the objective of this study was to determine 
the proliferation and differentiation potential of human FPSCs in a model system mimicking aspects of this environment. The first phase of the study assessed the role of TGF- $\beta 3$ and FGF-2, in addition to an altered oxygen tension environment, on the colony-forming unitfibroblast (CFU-F) capacity and growth kinetics of human FPSCs during monolayer expansion. The subsequent chondrogenic capacity of these cells was then quantified in normoxic $(20 \%)$ and low $(5 \%)$ oxygen conditions in a pellet culture system. Having identified appropriate expansion conditions, we next sought to determine the effect of biomaterial substrate (agarose and fibrin hydrogels) and biochemical cues in either low (5\%) or normoxic (20\%) oxygen environments on the development of cartilaginous tissues engineered using human FPSCs. We hypothesised that in vitro conditions mimicking aspects of the regenerative environment of microfracture, specifically encapsulation in fibrin hydrogels and maintenance in low oxygen conditions, would facilitate the development of cartilaginous tissues engineering using FPSCs.

\section{Materials and Methods}

\section{Cell isolation and expansion}

Ethical approval for the study was obtained from the institutional review board of the Mater Misericordiae University Hospital with IFPs being obtained from 7 patients with knee OA at joint arthroplasty. The infrapatellar fat pads (IFPs) were washed thoroughly in phosphatebuffered saline (PBS) and tissue specimens were finely diced with care taken to exclude fibrotic regions. Samples were weighed and incubated with $0.25 \%(\mathrm{w} / \mathrm{v})$ collagenase (Worthington Biochemical, Ireland) for 4 hours at $37^{\circ} \mathrm{C}$ under constant rotation. After tissue digestion, cells were washed in PBS, filtered through a $40 \mu \mathrm{m}$ nylon cell strainer and centrifuged at $650 \mathrm{~g}$ for $5 \mathrm{mins}$. Supernatant was discarded to remove floating adipocytes and 
cells resuspended in standard expansion medium (EM) consisting of high glucose DMEM containing $10 \%$ foetal bovine serum and antibiotics (100 units $/ \mathrm{ml}$ penicillin and $100 \mu \mathrm{g} / \mathrm{ml}$ streptomycin) (all from GIBCO, Biosciences, Dublin, Ireland). After counting in 3\% final acetic acid (to lyse blood cells) and Trypan blue, cells were seeded at a density of $5 \times 10^{3}$ live cells $/ \mathrm{cm}^{2}$ in T-75 flasks (Sarstedt, Wexford, Ireland). Further groups were expanded in EM supplemented with either FGF-2 $(5 \mathrm{ng} / \mathrm{ml})$, TGF- $\beta 3(0.5 \mathrm{ng} / \mathrm{ml})$ or both FGF-2 $(5 \mathrm{ng} / \mathrm{ml})$ and TGF- $\beta 3(0.5 \mathrm{ng} / \mathrm{ml})$ (all from ProSpec-Tany TechnoGene Ltd., Israel). The concentration of growth factors utilized here was motivated by previous studies ${ }^{16,25,29,31}$.

All groups were expanded at either $5 \%$ or $20 \%$ oxygen. Non-adherent cells were removed at the first medium change after $72 \mathrm{~h}$. After colony formation during passage 0 (P0) (8-10 days), cells were detached with $0.05 \%$ trypsin-EDTA (Sigma-Aldrich, Arklow, Ireland) and sub-cultured at a density of $5 \times 10^{3} \mathrm{cells} / \mathrm{cm}^{2}(\mathrm{P} 1)$. Cultures were expanded to passage two (P2) at a seeding density of $5 \times 10^{3}$ cells $/ \mathrm{cm}^{2}$. Complete medium exchanges were performed twice weekly.

\section{Colony-forming unit-fibroblast (CFU-F) assay}

For the CFU-F assay freshly isolated cells from 4 donors were plated in $58 \mathrm{~cm}^{2}$ petri dishes at a density of $135 \mathrm{cells} / \mathrm{cm}^{2}$ with EM and the various growth factor formulations. Triplicate dishes were plated for all conditions. After 14 days, cells were fixed with $2 \%$ paraformaldehyde (PFA), stained with 1\% crystal violet (Sigma-Aldrich, Arklow, Ireland) and colony numbers ( $>50$ cells) counted. Total colony number was used to determine the total number of population doublings that occurred during P0 and hence the population doubling time. For the purposes of comparison between groups, colony size was defined as the average diameter of the 10 largest colonies formed. 
In vitro chondrogenesis in pellet culture

P2 cells $(250,000)$ from 4 donors were centrifuged in $1.5 \mathrm{~mL}$ micro tubes by centrifugation at $650 \mathrm{~g}$ for $5 \mathrm{~min}$. Pellets were cultured for 21 days in $1 \mathrm{~mL}$ of serum-free medium consisting of hgDMEM supplemented with standard antibiotic mixture (100 units/ml penicillin and 100 $\mu \mathrm{g} / \mathrm{ml}$ streptomycin) (Invitrogen, Paisley, UK), $100 \mu \mathrm{g} / \mathrm{ml}$ sodium pyruvate, $40 \mu \mathrm{g} / \mathrm{ml} \mathrm{L-}$ proline, $1.5 \mathrm{mg} / \mathrm{ml} \mathrm{BSA,} 4.7 \mu \mathrm{g} / \mathrm{mL}$ linoleic acid, $1 \times$ insulin-transferrin-selenium, $50 \mu \mathrm{g} / \mathrm{ml}$ L-ascorbic acid-2-phosphate, $100 \mathrm{nM}$ dexamethasone (all from Sigma-Aldrich, Ireland) and $10 \mathrm{ng} / \mathrm{mL}$ TGF- $\beta 3$.

Engineering cartilaginous grafts in fibrin and agarose hydrogels

IFPs were obtained from 3 different patients with knee OA at joint arthroplastly. FPSCs were isolated as described above, and expanded at $20 \%$ oxygen in media supplemented with $5 \mathrm{ng} / \mathrm{ml}$ fibroblast-growth factor-2 (FGF-2). FPSCs from all three donors were pooled prior to hydrogel encapsulation to create a superlot. In the first study expanded cells were suspended in either $2 \%$ agarose (Type VII, Sigma) or in fibrin hydrogels at a density of 20 million cells/ml. Fibrinogen (Sigma-Aldrich, Ireland) was dissolved in aprotinin solution (Nordic Pharma, UK). Cells were mixed with this solution and thrombin added to crosslink the gel. The solution was immediately injected into an agarose mould to yield fibrin cylindrical hydrogels $(50 \mathrm{mg} / \mathrm{ml}$ fibrinogen, $5000 \mathrm{KIU} / \mathrm{ml}$ aprotinin, and $2.5 \mathrm{U} / \mathrm{ml}$ thrombin final concentrations) with the same dimensions as the agarose hydrogels. Construct cylinders of dimensions $\varnothing 5 \times 2 \mathrm{~mm}$ were produced and maintained in a chemically defined chondrogenic media supplemented with TGF- $\beta 3(10 \mathrm{ng} / \mathrm{ml})$ at either $20 \%$ or $5 \%$ oxygen. In a second study, 
fibrin hydrogels were prepared in the same manner and cultured in STD media formulation with or without the addition of $5 \%$ FBS (STD $+5 \%$ FBS), and cultured at either $20 \%$ or $5 \%$ oxygen. Constructs were maintained in culture for 42 days.

\section{Biochemical analysis}

Pellets ( $n=4$ per experimental group for each of the 4 donors) and hydrogels ( $n=4$ per experimental group using FPSCs from the superlot) were digested in papain $(125 \mu \mathrm{g} / \mathrm{ml})$ in 0.1 M sodium acetate, $5 \mathrm{mM}$ cysteine $\mathrm{HCl}, 0.05 \mathrm{M}$ EDTA, $\mathrm{pH} 6.0$ (all from Sigma-Aldrich, Arklow, Ireland) at $60^{\circ} \mathrm{C}$ for 18 hours. Total DNA content was measured using a Quant-iT PicoGreen ${ }^{\circledR}$ dsDNA kit (Molecular Probes, Biosciences, Dublin, Ireland) with a lambda DNA standard. The proteoglycan content was estimated by quantifying the amount of sulfated glycosaminoglycan (sGAG) in digested pellets using the dimethylmethylene blue dye-binding assay (Blyscan, Biocolor Ltd., Carrickfergus, Northern Ireland), with a chondroitin sulfate standard.

\section{Histology}

Pellets and hydrogels ( $n=2$ per group) were fixed in $4 \%$ paraformaldehyde (Sigma-Aldrich, Arklow, Ireland), wax embedded and sectioned at $5 \mu \mathrm{m}$. Sections were stained for sGAG with $1 \%$ alcian blue $8 \mathrm{GX}$ (Sigma-Aldrich, Arklow, Ireland) in $0.1 \mathrm{M} \mathrm{HCl}$, and for collagen with picro-sirius red.

The deposition of collagen types I, II and $\mathrm{X}$ were identified through immunohistochemistry. Briefly sections were rinsed with PBS and quenched of peroxidase activity for 20 mins and treated with chondroitinase ABC (Sigma, 0.25 units $/ \mathrm{ml}$ ) in a 
humidified environment at $37^{\circ} \mathrm{C}$ for $1 \mathrm{hr}$ to enhance permeability of the extracellular matrix by removal of chondroitin sulphate. Slides were again rinsed with PBS and blocked with 10\% goat serum for 30 mins. Sections were incubated with collagen type I (ab6308, 1:400; 5.7 $\mathrm{mg} / \mathrm{mL})$, collagen type II (ab3092,1:100; $1 \mathrm{mg} / \mathrm{mL}$ ) or collagen type X (ab49945,1:200; 1.4 $\mathrm{mg} / \mathrm{mL}$ ) primary antibody (mouse monoclonal, Abcam, Cambridge, UK) for $1 \mathrm{hr}$ at room temperature. After washing in PBS, the secondary antibody for type I and type II collagen (Anti-Mouse IgG Biotin antibody produced in goat) (concentration $1 \mathrm{~g} / \mathrm{L}$ ) binding was applied for $1 \mathrm{hr}$. Colour was developed using the Vectastain $\mathrm{ABC}$ reagent (Vectastain $\mathrm{ABC}$ kit, Vector Laboratories, UK) for 45 min and 5 min exposure to peroxidase DAB substrate kit (Vector laboratories, UK). Slides were dehydrated through ethanol and xyelene and mounted with Vectamount medium (Vector Laboratories, UK). Positive and negative controls (cartilage and ligament) were included in the immunohistochemistry staining protocol for each batch.

\section{Statistical Analysis}

All statistical analyses were performed using GraphPad Prism (Version 4.3) software. Numerical and graphical results are reported in the form of mean \pm standard error from the mean (SE). Groups were compared with two way ANOVA with Bonferroni post-tests, with oxygen tension and growth factor formulation as the independent variables. 


\section{Results}

Expansion in FGF-2 alters the colony forming unit capacity of diseased human FPSCs

Colonies generated from FPSCs expanded in FGF-2 generally appeared larger than those expanded in standard EM, particularly in lower oxygen environments (Fig. 1). When quantified, significant donor variability in CFU-F numbers were observed (Fig. 2). Both growth factor supplementation $(\mathrm{p}<0.001)$ and oxygen tension $(\mathrm{p}<0.005)$ had an overall effect on the CFU-F efficiency. Supplementation of EM with FGF-2 gave rise to significantly lower colony numbers compared to standard expansion conditions (3/4 donors). In general, expansion in the presence of TGF- $\beta 3$ did not significantly affect colony numbers compared to standard EM (3/4 donors).

Both growth factor supplementation $(\mathrm{p}<0.0001)$ and oxygen tension $(\mathrm{p}<0.005)$ had an overall effect on colony size (all donors pooled), with significantly larger colonies observed in FGF-2 supplemented media at both oxygen tensions compared to standard EM $(p<0.05)$ (Fig. 3a). Smaller colonies were observed in the TGF- $\beta 3$ only group at $5 \%$ oxygen compared to standard EM $(\mathrm{p}<0.05)$. Colony size in the FGF-2 group was significantly greater at $5 \%$ oxygen compared to $20 \%$ oxygen $(\mathrm{p}<0.01)$.

Oxygen tension did not significantly affect cell doubling time during passage 0 (Fig. 3b). There was a greater number of population doublings during P0 in FGF-2 supplemented media compared to the standard expansion media at $20 \%$ oxygen $(\mathrm{p}<0.05)$ (Fig. 3c). Supplementation with both FGF-2 and TGF- $\beta 3$ was observed to significantly reduce cell doubling times compared to standard expansion media $(\mathrm{p}<0.05)$ (Fig. 3b). The number of population doublings during P0 was also greater for cells expanded in the presence of both FGF-2 and TGF- $\beta 3$ (Fig. 3c). 
Expansion in FGF-2 followed by differentiation in a low oxygen environment synergistically enhances the chondrogenic potential of diseased human FPSCs

Expansion in the presence of FGF-2 significantly enhanced sGAG production (sGAG/DNA) for FPSCs undergoing chondrogenic differentiation in pellet culture compared to cells expanded in standard EM $(4.3 \pm 0.08 \mu \mathrm{g} / \mu \mathrm{g}$ vs. $2.3 \pm 0.013 \mu \mathrm{g} / \mu \mathrm{g} ; \mathrm{p}<0.001)$ (Fig. 4). This result was also observed for MSCs expanded at 5\% oxygen (data not shown). Expansion in the presence of FGF-2, followed by differentiation at 5\% oxygen, resulted in the highest levels of sGAG production $(5.9 \pm 0.34 \mu \mathrm{g} / \mu \mathrm{g} ; \mathrm{p}<0.05)$. Expansion in the presence of TGF- $\beta 3$, or both FGF-2 and TGF- $\beta 3$, did not significantly improve sGAG accumulation within pellets compared to standard expansion conditions (data not shown). All pellets stained positive for alcian blue and picro-sirius red, with pellets expanded in the presence of FGF-2 generally appearing larger and more intensely stained, particularly around the periphery of pellets (Fig. 5). Pellets stained positively for type II collagen, indicating the formation of a cartilage-like extracellular matrix.

Encapsulation in fibrin hydrogels and maintenance in a low oxygen environment supports the development of cartilaginous grafts engineered using diseased human FPSCs

Having identified expansion and differentiation conditions that promoted robust chondrogenesis of FPSCs in pellet culture, we next explored the use of cells expanded in FGF-2 and encapsulated into either fibrin or agarose hydrogels for engineering functional cartilaginous grafts. After 42 days in culture there was a significant decrease in DNA content in agarose hydrogels, but an increase for fibrin hydrogels over day 0 levels. In addition, 
sGAG production was higher in fibrin hydrogels (Fig. 6), and was further enhanced by differentiation in low oxygen conditions, however significant contraction of fibrin hydrogels occurred after 42 days of culture (Fig. 7). Fibrin constructs also stained positively for sulphated proteoglycan and type II collagen, but only weakly for type I and X collagen (Fig. 8). Supplementation with 5\% FBS prevented contraction of fibin constructs (Fig 7A) and had no effect on total sGAG production (Fig. 7D). Due to the significant change in volume and therefore decrease in mass of hydrogels not supplemented with FBS, the sGAG content as a percentage of wet weight for this group was approximately 4-5 fold higher than hydrogels maintained in the presence of 5\% FBS (Fig 7C). Maintenance at 5\% $\mathrm{O}_{2}$ increased sGAG production for both these groups (Fig. 7D).

\section{Discussion}

Identifying environmental conditions that enhance the proliferation and chondrogenic potential of MSCs is an essential prerequisite for tissue engineering and regenerative medicine therapies targeting damaged and diseased articular cartilage. In this study it was found that expansion of diseased human FPSCs in the presence of FGF-2 increases the cell yield and enhances their chondrogenic potential. As evident by the lower number of colonies formed in media supplemented with FGF-2, and the subsequent enhanced sGAG synthesis rates of the progeny of these progenitors, it would appear that expansion in the presence of this growth factor appears to help select and/or expand a more proliferative and chondrogenic sub-population from the heterogeneous cell population isolated from the IFP. Furthermore, chondrogenic differentiation of FPSCs expanded in the presence of FGF-2 was further enhanced by subsequent maintenance in a low oxygen environment. Having identified appropriate expansion conditions, we sought to identify differentiation conditions that might 
facilitate the development of cartilaginous grafts engineered using human FPSCs. We hypothesised that recapitulating aspects of the in vivo regenerative environment known to promote chondrogenesis of MSCs, specifically fibrin deposition, a low oxygen environment and the presence of elevated levels of growth factors, would facilitate the development of grafts engineered using FPSCs. This was indeed the case, with fibrin hydrogels found to better supported the development of a cartilaginous tissue compared to agarose hydrogels using human FPSCs, demonstrating both the importance of the local substrate for tissue engineering applications and for the potential utility of FPSCs for such strategies.

As has been observed for MSCs isolated from other tissues such as bone marrow ${ }^{56}$, some donor variability was also observed in the colony forming efficiency of cells isolated from the IFP. The colony forming efficiency was also affected by growth factor supplementation. The exact mechanism for this is unclear, although it suggests that FGF-2 may also play a role in preventing a sub-population of otherwise colony forming cells from either adhering or expanding in monolayer culture. Previous studies have also observed significant variability with human mesenchymal stem cell populations, in terms of proliferative capacity and subsequent multipotentiality, which does not appear to be a function of age or gender ${ }^{57-58}$. Serum effects and/or laboratory procedure and protocols may also at least partially contribute to such variability ${ }^{14}$. Colony size was also affected by expansion conditions, with dramatically larger colonies observed in groups supplemented with FGF-2 at 5\% oxygen tension. This larger colony size is indicative of more rapid cell proliferation, although cell doubling times for FPSCs expanded in FGF-2 were not found to be statistically lower than standard expansion conditions when data was pooled from all donors (Fig. 3B). An alternative explanation for the smaller colony size observed in standard expansion conditions is that the higher number of colonies that were formed results in contact inhibition thereby limiting cell proliferation. Cell doubling time was significantly lower for 
FPSCs expanded in the presence of both FGF-2 and TGF- $\beta 3$, demonstrating that these growth factors act synergistically to promote more rapid proliferation. The number of population doublings occurring prior to reaching confluence during passage 0 (the cell yield) was also higher for FPSCs supplemented with FGF-2 or FGF-2 and TGF- $\beta 3$, which was likely primarily to a smaller cell size as has been observed for bone marrow derived MSCs expanded in the presence of FGF-2 ${ }^{14,27}$.

In agreement with previous studies using human FPSCs, expansion in the presence of FGF-2 enhanced subsequent chondrogenesis in a pellet culture system ${ }^{25}$. The finding that low oxygen conditions during pellet culture also improves chondrogenesis of FPSCs is also in agreement with the same authors ${ }^{51}$. The results of our study also suggest that these two factors can act synergistically to enhance chondrogenesis of FPSCs, with expansion in FGF-2 appearing to be a more potent pro-chondrogenic factor than differentiation at a low oxygen tension. Importantly for tissue engineering applications, the benefits of differentiation in a low oxygen environment were also observed following encapsulation into fibrin hydrogels.

Encapsulation of human FPSCs in agarose hydrogels has been shown to suppress their chondrogenic potential compared to pellet culture ${ }^{59}$. Given the well documented advantages of hydrogel encapsulation for tissue engineering applications, we sought to explore the use of alternative hydrogel substrates as a means to generate cartilaginous grafts. Fibrin hydrogelbased biomaterials offer high biocompatibility and provide great promise as a scaffold material for cartilage repair ${ }^{60}$. Indeed fibrin hydrogels perhaps best mimic the body's own regenerative substrate, which under low oxygen conditions facilities cartilage tissue formation. In this study we observed improved chondrogenesis of human FPSCs in fibrin compared to agarose hydrogels, which was further enhanced under low oxygen conditions. This provides support for our hypothesis that recapitulating aspects of the microfracture environment, namely the use of a fibrin substrate and a low oxygen microenvironment, is a 
promising approach for cartilage tissue engineering. Of course, the microfracture technique generally leads to the formation of mechanically inferior fibro-cartilaginous tissue compared to normal cartilage. This may be driven, at least in part, by the challenging inflammatory and mechanical environment within a damaged joint that can promote a more fibrous phenotype at the expense of a chondrogenic phenotype ${ }^{61-63}$. In vitro studies have demonstrated the importance of biophysical cues in determining the fate of chondrogenic cells ${ }^{64}$, with tensile loading having been shown to promote type I collagen synthesis ${ }^{65}$, while alternative cues such as dynamic compression ${ }^{66-70}$ and hydrostatic pressure ${ }^{71-73}$ have been shown to enhance sGAG and type II collagen synthesis and suppress markers of hypertrophy ${ }^{74-75}$. The results of computational models point to a complex mechanical environment in vivo with spatially varying signals that may drive MSC differentiation down undesired pathways ${ }^{61}$. An inherent advantage of in vitro tissue engineering is that these factors can be controlled using

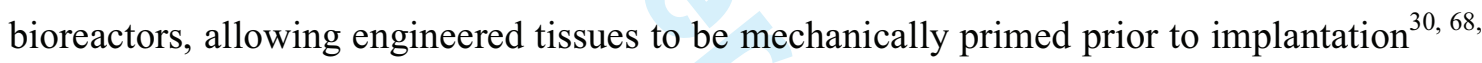
76-81. Inflammatory cytokines present in damaged or diseased joints may also alter MSC proliferation kinetics and potentially inhibit chondrogenesis. Various inflammatory cytokines have been shown to influence the proliferative potential of $\mathrm{MSCs}^{82-84}$. Catabolic factors such as interleukin (IL)-1 $\alpha$ and/or tumor necrosis factor (TNF)- $\alpha$ have been shown to suppress chondrogenesis of MSCs ${ }^{85-88}$. Understanding how oxygen, mechanics, various cytokines and substrate interact to regulate cell fate is central to regenerating hyaline cartilage using MSCs.

At this stage no definitive explanation can be provided for why fibrin provides a more chondrogenic environment than agarose hydrogels for human FPSCs. Somewhat surprisingly, we have recently observed the opposite result using immature porcine bone marrow derived MSCs, where agarose better supported chondrogenesis compared to fibrin hydrogels ${ }^{75}$. The cell mediated contraction observed in fibrin hydrogels, which in turn supports greater cellcell interactions, is hypothesized as one potential mechanism for this improvement in 
chondrogenesis using diseased human FPSCs. Cells cannot directly adhere to agarose, thereby limiting contraction, migration, proliferation and hence cell-cell interactions that appear critical for supporting chondrogenesis of adult MSCs. A potential limitation of the use of fibrin for tissue engineering applications is its inherent capacity to undergo contraction when cells are cultured on it, rendering the final geometry of the engineered graft unpredictable. In this work we demonstrated that supplementation of 5\% FBS during culture inhibits contraction of these hydrogels. The exact mechanism by which FBS prevents this is unclear, although it may be due to FPSCs proliferating extensively on the surface of the fibrin hydrogels in the presence of serum, thereby providing a supporting cell and tissue layer that resists contraction.

In conclusion, the colony forming efficiency and growth kinetics of human infrapatellar fat pad derived stem cells depends on the local oxygen tension and growth factors in which the cells are expanded. Expansion in the presence of FGF-2 appears to help to select for, and/or preferentially expand, a sub-population of the total mononuclear cell fraction within the IFP, the progeny of which are more chondrogenic than cells expanded in standard conditions. Recapitulating aspects of the in vivo regenerative environment, specifically encapsulation in fibrin and maintenance in a low oxygen environment, facilitated the development of cartilaginous grafts engineered using FPSCs expanded in the presence of FGF-2. These results support the future use of FPSCs in combination with fibrin hydrogels as a therapy to treat damaged articular cartilage.

\section{Conflicts of Interest}

The authors have nothing to disclose. 


\section{Acknowledgements}

DJK is funded by Science Foundation Ireland under the President of Ireland Young Researcher Award (08/Y15/B1336) and by a European Research Council Starter Award (StemRepair - Project number 258463). EJ and DM hold funding from EU FP7, National Institute of Health Research and Wellcome Trust/EPSRC through WELMEC, a Centre of Excellence in Medical Engineering, under grant number WT 088908/Z/09/Z.

\section{References}

1. Dragoo JL, Samimi B, Zhu M, Hame SL, Thomas BJ, Lieberman JR, et al. Tissueengineered cartilage and bone using stem cells from human infrapatellar fat pads. J Bone Joint Surg Br.85:740-7. 2003.

2. Wickham MQ, Erickson GR, Gimble JM, Vail TP, Guilak F. Multipotent stromal cells derived from the infrapatellar fat pad of the knee. Clin Orthop Relat Res.196-212. 2003.

3. English A, Jones EA, Corscadden D, Henshaw K, Chapman T, Emery P, et al. A comparative assessment of cartilage and joint fat pad as a potential source of cells for autologous therapy development in knee osteoarthritis. Rheumatology.46:1676-83. 2007.

4. Lopa S, Colombini A, de Girolamo L, Sansone V, Moretti M. New Strategies in Cartilage Tissue Engineering for Osteoarthritic Patients: Infrapatellar Fat Pad as an Alternative Source of Progenitor Cells. Journal of Biomaterials and Tissue Engineering.1:408. 2011.

5. Buckley CT, Vinardell T, Thorpe SD, Haugh MG, Jones E, McGonagle D, et al. Functional properties of cartilaginous tissues engineered from infrapatellar fat pad-derived mesenchymal stem cells. Journal of Biomechanics.43:920-6. 2010.

6. Jurgens WJFM, Van Dijk A, Doulabi BZ, Niessen FB, Ritt MJPF, Van Milligen FJ, et al. Freshly isolated stromal cells from the infrapatellar fat pad are suitable for a one-step surgical procedure to regenerate cartilage tissue. Cytotherapy.11:1052-64. 2009.

7. Toghraie FS, Chenari N, Gholipour MA, Faghih Z, Torabinejad S, Dehghani S, et al. Treatment of osteoarthritis with infrapatellar fat pad derived mesenchymal stem cells in Rabbit. Knee.

8. Marsano A, Millward-Sadler SJ, Salter DM, Adesida A, Hardingham T, Tognana E, et al. Differential cartilaginous tissue formation by human synovial membrane, fat pad, meniscus cells and articular chondrocytes. Osteoarthritis and Cartilage.15:48-58. 2007.

9. Toghraie FS, Chenari N, Gholipour MA, Faghih Z, Torabinejad S, Dehghani S, et al. Treatment of osteoarthritis with infrapatellar fat pad derived mesenchymal stem cells in Rabbit. Knee.18:71-5. 2011. 
10. Vinardell T, Buckley CT, Thorpe SD, Kelly DJ. Composition-function relations of cartilaginous tissues engineered from chondrocytes and mesenchymal stem cells isolated from bone marrow and infrapatellar fat pad. J Tissue Eng Regen Med. 2010.

11. Vinardell T, Sheehy EJ, Buckley CT, Kelly DJ. A comparison of the functionality and in vivo phenotypic stability of cartilaginous tissues engineered from different stem cells sources Tissue Engineering Part A. 2012.

12. Lee SY, Nakagawa T, Reddi AH. Induction of chondrogenesis and expression of superficial zone protein (SZP)/lubricin by mesenchymal progenitors in the infrapatellar fat pad of the knee joint treated with TGF- $\beta 1$ and BMP-7. Biochemical and Biophysical Research Communications.376:148-53. 2008.

13. Lee SY, Nakagawa T, Reddi AH. Mesenchymal progenitor cells derived from synovium and infrapatellar fat pad as a source for superficial zone cartilage tissue engineering: Analysis of superficial zone protein/lubricin expression. Tissue Engineering Part A.16:317-25. 2010.

14. Solchaga LA, Penick K, Porter JD, Goldberg VM, Caplan AI, Welter JF. FGF-2 enhances the mitotic and chondrogenic potentials of human adult bone marrow-derived mesenchymal stem cells. J Cell Physiol.203:398-409. 2005.

15. Jung S, Sen A, Rosenberg L, Behie LA. Identification of growth and attachment factors for the serum-free isolation and expansion of human mesenchymal stromal cells. Cytotherapy.12:637-57. 2010.

16. Estes BT, Diekman BO, Guilak F. Monolayer cell expansion conditions affect the chondrogenic potential of adipose-derived stem cells. Biotechnology and Bioengineering.99:986-95. 2008.

17. Reyes M, Lund T, Lenvik T, Aguiar D, Koodie L, Verfaillie CM. Purification and ex vivo expansion of postnatal human marrow mesodermal progenitor cells. Blood.98:2615-25. 2001.

18. Mastrogiacomo M, Cancedda R, Quarto R. Effect of different growth factors on the chondrogenic potential of human bone marrow stromal cells. Osteoarthritis and Cartilage.9:S36-S40. 2001.

19. Banfi A, Muraglia A, Dozin B, Mastrogiacomo M, Cancedda R, Quarto R. Proliferation kinetics and differentiation potential of ex vivo expanded human bone marrow stromal cells: Implications for their use in cell therapy. Experimental Hematology.28:707-15. 2000 .

20. Bianchi G, Banfi A, Mastrogiacomo M, Notaro R, Luzzatto L, Cancedda R, et al. Ex vivo enrichment of mesenchymal cell progenitors by fibroblast growth factor 2. Experimental Cell Research.287:98-105. 2003.

21. Martin I, Muraglia A, Campanile G, Cancedda R, Quarto R. Fibroblast growth factor2 supports ex vivo expansion and maintenance of osteogenic precursors from human bone marrow. Endocrinology.138:4456-62. 1997.

22. Tsutsumi S, Shimazu A, Miyazaki K, Pan H, Koike C, Yoshida E, et al. Retention of multilineage differentiation potential of mesenchymal cells during proliferation in response to FGF. Biochemical and Biophysical Research Communications.288:413-9. 2001.

23. Zaragosi LE, Ailhaud G, Dani C. Autocrine fibroblast growth factor 2 signaling is critical for self-renewal of human multipotent adipose-derived stem cells. Stem Cells.24:2412-9. 2006.

24. Jansen EJP, Emans PJ, Guldemond NA, Van Rhijn LW, Welting TJM, Bulstra SK, et al. Human periosteum-derived cells from elderly patients as a source for cartilage tissue engineering? Journal of tissue engineering and regenerative medicine.2:331-9. 2008. 
25. Khan WS, Tew SR, Adesida AB, Hardingham TE. Human infrapatellar fat padderived stem cells express the pericyte marker $3 \mathrm{G} 5$ and show enhanced chondrogenesis after expansion in fibroblast growth factor-2. Arthritis Research and Therapy.10. 2008.

26. Buckley CT, Kelly DJ. Expansion in the presence of FGF-2 enhances the functional development of cartilaginous tissues engineered using infrapatellar fat pad derived MSCs. J Mech Behav Biomed Mater.11:102-11. 2012.

27. Solchaga LA, Penick K, Goldberg VM, Caplan AI, Welter JF. Fibroblast growth factor-2 enhances proliferation and delays loss of chondrogenic potential in human adult bone-marrow-derived mesenchymal stem cells. Tissue Engineering - Part A.16:1009-19. 2010 .

28. Estes BT, Wu AW, Storms RW, Guilak F. Extended passaging, but not aldehyde dehydrogenase activity, increases the chondrogenic potential of human adipose-derived adult stem cells. Journal of Cellular Physiology.209:987-95. 2006.

29. Ng KW, Lima EG, Bian L, O'Conor CJ, Jayabalan PS, Stoker AM, et al. Passaged adult chondrocytes can form engineered cartilage with functional mechanical properties: A canine model. Tissue Engineering - Part A.16:1041-51. 2010.

30. Bian L, Fong JV, Lima EG, Stoker AM, Ateshian GA, Cook JL, et al. Dynamic mechanical loading enhances functional properties of tissue-engineered cartilage using mature canine chondrocytes. Tissue Engineering - Part A.16:1781-90. 2010.

31. Jakob M, Démarteau O, Schäfer D, Hintermann B, Dick W, Heberer M, et al. Specific growth factors during the expansion and redifferentiation of adult human articular chondrocytes enhance chondrogenesis and cartilaginous tissue formation in vitro. Journal of Cellular Biochemistry.81:368-77. 2001.

32. Khan IM, Evans SL, Young RD, Blain EJ, Quantock AJ, Avery N, et al. Fibroblast growth factor 2 and transforming growth factor $\beta 1$ induce precocious maturation of articular cartilage. Arthritis and Rheumatism.63:3417-27. 2011.

33. Ma T, Grayson WL, Fröhlich M, Vunjak-Novakovic G. Hypoxia and stem cell-based engineering of mesenchymal tissues. Biotechnology Progress.25:32-42. 2009.

34. Carrancio S, López-Holgado N, Sánchez-Guijo FM, Villarón E, Barbado V, Tabera S, et al. Optimization of mesenchymal stem cell expansion procedures by cell separation and culture conditions modification. Experimental Hematology.36:1014-21. 2008.

35. Dos Santos F, Andrade PZ, Boura JS, Abecasis MM, Da Silva CL, Cabral JMS. Ex vivo expansion of human mesenchymal stem cells: A more effective cell proliferation kinetics and metabolism under hypoxia. Journal of Cellular Physiology.223:27-35. 2010.

36. Grayson WL, Zhao F, Bunnell B, Ma T. Hypoxia enhances proliferation and tissue formation of human mesenchymal stem cells. Biochemical and Biophysical Research Communications.358:948-53. 2007.

37. Grayson WL, Zhao F, Izadpanah R, Bunnell B, Ma T. Effects of hypoxia on human mesenchymal stem cell expansion and plasticity in 3D constructs. Journal of Cellular Physiology.207:331-9. 2006.

38. Krinner A, Zscharnack M, Bader A, Drasdo D, Galle J. Impact of oxygen environment on mesenchymal stem cell expansion and chondrogenic differentiation. Cell Proliferation.42:471-84. 2009.

39. Zscharnack M, Poesel C, Galle J, Bader A. Low oxygen expansion improves subsequent chondrogenesis of ovine bone-marrow-derived mesenchymal stem cells in collagen type I hydrogel. Cells Tissues Organs.190:81-93. 2009.

40. Muller J, Benz K, Ahlers M, Gaissmaier C, Mollenhauer J. Hypoxic conditions during expansion culture prime human mesenchymal stromal precursor cells for chondrogenic differentiation in three-dimensional cultures. Cell Transplant. 2011. 
41. Xu Y, Malladi P, Chiou M, Bekerman E, Giaccia AJ, Longaker MT. In vitro expansion of adipose-derived adult stromal cells in hypoxia enhances early chondrogenesis. Tissue Engineering.13:2981-93. 2007.

42. Egli RJ, Bastian JD, Ganz R, Hofstetter W, Leunig M. Hypoxic expansion promotes the chondrogenic potential of articular chondrocytes. Journal of Orthopaedic Research.26:977-85. 2008.

43. Henderson JH, Ginley NM, Caplan AI, Niyibizi C, Dennis JE. Low oxygen tension during incubation periods of chondrocyte expansion is sufficient to enhance postexpansion chondrogenesis. Tissue Engineering - Part A.16:1585-93. 2010.

44. Wang DW, Fermor B, Gimble JM, Awad HA, Guilak F. Influence of oxygen on the proliferation and metabolism of adipose derived adult stem cells. Journal of Cellular Physiology.204:184-91. 2005.

45. Meyer EG, Buckley CT, Thorpe SD, Kelly DJ. Low oxygen tension is a more potent promoter of chondrogenic differentiation than dynamic compression. Journal of Biomechanics.43:2516-23. 2010.

46. Kanichai M, Ferguson D, Prendergast PJ, Campbell VA. Hypoxia promotes chondrogenesis in rat mesenchymal stem cells: A role for AKT and hypoxia-inducible factor (HIF)-1? Journal of Cellular Physiology.216:708-15. 2008.

47. Robins JC, Akeno N, Mukherjee A, Dalal RR, Aronow BJ, Koopman P, et al. Hypoxia induces chondrocyte-specific gene expression in mesenchymal cells in association with transcriptional activation of Sox9. Bone.37:313-22. 2005.

48. Hirao M, Tamai N, Tsumaki N, Yoshikawa H, Myoui A. Oxygen tension regulates chondrocyte differentiation and function during endochondral ossification. J Biol Chem.281:31079-92. 2006.

49. Pilgaard L, Lund P, Duroux M, Fink T, Ulrich-Vinther M, Soballe K, et al. Effect of oxygen concentration, culture format and donor variability on in vitro chondrogenesis of human adipose tissue-derived stem cells. Regen Med.4:539-48. 2009.

50. Malladi $\mathrm{P}, \mathrm{Xu} \mathrm{Y}$, Chiou M, Giaccia AJ, Longaker MT. Effect of reduced oxygen tension on chondrogenesis and osteogenesis in adipose-derived mesenchymal cells. Am J Physiol Cell Physiol.290:C1139-46. 2006.

51. Khan WS, Adesida AB, Hardingham TE. Hypoxic conditions increase hypoxiainducible transcription factor 2alpha and enhance chondrogenesis in stem cells from the infrapatellar fat pad of osteoarthritis patients. Arthritis Res Ther.9:R55. 2007.

52. Buckley CT, Vinardell T, Kelly DJ. Oxygen tension differentially regulates the functional properties of cartilaginous tissues engineered from infrapatellar fat pad derived MSCs and articular chondrocytes. Osteoarthritis and Cartilage.18:1345-54. 2010.

53. Zhou S, Cui Z, Urban JP. Factors influencing the oxygen concentration gradient from the synovial surface of articular cartilage to the cartilage-bone interface: a modeling study. Arthritis Rheum.50:3915-24. 2004.

54. Williams 3rd RJ, Harnly HW. Microfracture: indications, technique, and results. Instructional course lectures.56:419-28. 2007.

55. McIlwraith CW, Frisbie DD. Microfracture: Basic science studies in the horse. Cartilage.1:87-95. 2010.

56. Digirolamo CM, Stokes D, Colter D, Phinney DG, Class R, Prockop DJ. Propagation and senescence of human marrow stromal cells in culture: A simple colony-forming assay identifies samples with the greatest potential to propagate and differentiate. British Journal of Haematology.107:275-81. 1999.

57. Bruder SP, Jaiswal N, Haynesworth SE. Growth kinetics, self-renewal, and the osteogenic potential of purified human mesenchymal stem cells during extensive 
subcultivation and following cryopreservation. Journal of Cellular Biochemistry.64:278-94. 1997.

58. Siddappa R, Licht R, van Blitterswijk C, de Boer J. Donor variation and loss of multipotency during in vitro expansion of human mesenchymal stem cells for bone tissue engineering. J Orthop Res.25:1029-41. 2007.

59. Liu Y, Buckley CT, Downey R, Mulhall KJ, Kelly DJ. The role of environmental factors in regulating the development of cartilaginous grafts engineered using osteoarthritic human infrapatellar fat pad derived stem cells. (in review).

60. Ahmed TAE, Dare EV, Hincke M. Fibrin: A versatile scaffold for tissue engineering applications. Tissue Engineering - Part B: Reviews.14:199-215. 2008.

61. Kelly DJ, Prendergast PJ. Mechano-regulation of stem cell differentiation and tissue regeneration in osteochondral defects. J Biomech.38:1413-22. 2005.

62. Kelly DJ, Prendergast PJ. Prediction of the optimal mechanical properties for a scaffold used in osteochondral defect repair. Tissue Eng. 12:2509-19. 2006.

63. Steck E, Fischer J, Lorenz H, Gotterbarm T, Jung M, Richter W. Mesenchymal Stem Cell Differentiation in an Experimental Cartilage Defect: Restriction of Hypertrophy to Bone-Close Neocartilage. Stem Cells and Development.18:969-78. 2009.

64. Kelly DJ, Jacobs CR. The role of mechanical signals in regulating chondrogenesis and osteogenesis of mesenchymal stem cells. Birth Defects Research Part C - Embryo Today: Reviews.90:75-85. 2010.

65. Connelly JT, Vanderploeg EJ, Mouw JK, Wilson CG, Levenston ME. Tensile loading modulates bone marrow stromal cell differentiation and the development of engineered fibrocartilage constructs. Tissue Engineering - Part A.16:1913-23. 2010.

66. Li Z, Yao SJ, Alini M, Stoddart MJ. Chondrogenesis of Human Bone Marrow Mesenchymal Stem Cells in Fibrin-Polyurethane Composites is Modulated by Frequency and Amplitude of Dynamic Compression and Shear Stress. Tissue Eng Part A. 2009.

67. Huang CY, Hagar KL, Frost LE, Sun Y, Cheung HS. Effects of cyclic compressive loading on chondrogenesis of rabbit bone-marrow derived mesenchymal stem cells. Stem Cells.22:313-23. 2004.

68. Thorpe SD, Buckley CT, Vinardell T, O'Brien FJ, Campbell VA, Kelly DJ. The Response of Bone Marrow-Derived Mesenchymal Stem Cells to Dynamic Compression Following TGF- $\beta 3$ Induced Chondrogenic Differentiation. Annals of Biomedical Engineering.1-14. 2010.

69. Kisiday JD, Frisbie DD, McIlwraith CW, Grodzinsky AJ. Dynamic compression stimulates proteoglycan synthesis by mesenchymal stem cells in the absence of chondrogenic cytokines. Tissue Engineering - Part A.15:2817-24. 2009.

70. Mouw JK, Connelly JT, Wilson CG, Michael KE, Levenston ME. Dynamic compression regulates the expression and synthesis of chondrocyte-specific matrix molecules in bone marrow stromal cells. Stem Cells.25:655-63. 2007.

71. Miyanishi K, Trindade MC, Lindsey DP, Beaupre GS, Carter DR, Goodman SB, et al. Dose- and time-dependent effects of cyclic hydrostatic pressure on transforming growth factor-beta3-induced chondrogenesis by adult human mesenchymal stem cells in vitro. Tissue Eng.12:2253-62. 2006.

72. Miyanishi K, Trindade MCD, Lindsey DP, Beaupre GS, Carter DR, Goodman SB, et al. Effects of hydrostatic pressure and transforming growth factor-beta 3 on adult human mesenchymal stem cell chondrogenesis in vitro. Tissue Engineering.12:1419-28. 2006.

73. Angele P, Yoo JU, Smith C, Mansour J, Jepsen KJ, Nerlich M, et al. Cyclic hydrostatic pressure enhances the chondrogenic phenotype of human mesenchymal progenitor cells differentiated in vitro. Journal of Orthopaedic Research.21:451-7. 2003. 
74. Vinardell T, Rolfe RA, Buckley CT, Meyer EG, Ahearne M, Murphy P, et al. Hydrostatic pressure acts to stabilise a chondrogenic phenotype in porcine joint tissue derived stem cells. Eur Cell Mater.23:121-32; discussion 33-4. 2012.

75. Steward AJ, Thorpe SD, Vinardell T, Buckley CT, Wagner DR, Kelly DJ. Cell-matrix interactions regulate mesenchymal stem cell response to hydrostatic pressure. Acta Biomaterialia.8:2153-9. 2012.

76. Thorpe SD, Buckley CT, Vinardell T, O'Brien FJ, Campbell VA, Kelly DJ. Dynamic compression can inhibit chondrogenesis of mesenchymal stem cells. Biochemical and Biophysical Research Communications.377:458-62. 2008.

77. Huang AH, Farrell MJ, Kim M, Mauck RL. Long-term dynamic loading improves the mechanical properties of chondrogenic mesenchymal stem cell-laden hydrogels. European Cells and Materials.19:72-85. 2010.

78. Huang AH, Farrell MJ, Mauck RL. Mechanics and mechanobiology of mesenchymal stem cell-based engineered cartilage. Journal of Biomechanics.43:128-36. 2010.

79. Mauck RL, Soltz MA, Wang CCB, Wong DD, Chao PHG, Valhmu WB, et al. Functional tissue engineering of articular cartilage through dynamic loading of chondrocyteseeded agarose gels. Journal of Biomechanical Engineering.122:252-60. 2000.

80. Meyer EG, Buckley CT, Steward AJ, Kelly DJ. The effect of cyclic hydrostatic pressure on the functional development of cartilaginous tissues engineered using bone marrow derived mesenchymal stem cells. Journal of the Mechanical Behavior of Biomedical Materials.4:1257-65. 2011.

81. Liu Y, Buckley CT, Downey R, Mulhall KJ, Kelly DJ. The Role of Environmental Factors in Regulating the Development of Cartilaginous Grafts Engineered Using Osteoarthritic Human Infrapatellar Fat Pad-Derived Stem Cells. Tissue Eng Part A. 2012.

82. Warnawin E, Burakowski T, Gajewski M, Radzikowska A, Kornatka A, Michalak C, et al. Preservation of chondrogenic potential of mesenchymal stem cells isolated from osteoarthritic patients during proliferation in response to platelet-derived growth factor (PDGF). Central-European Journal of Immunology.30:26-31. 2005.

83. Lacey DC, Simmons PJ, Graves SE, Hamilton JA. Proinflammatory cytokines inhibit osteogenic differentiation from stem cells: implications for bone repair during inflammation. Osteoarthritis and Cartilage.17:735-42. 2009.

84. Lei J, Cheng LM, Tan MQ. Effects of serum and cytokines on the proliferation of human marrow mesenchymal stem cells. Bulletin of Hunan Medical University.28:469-72. 2003.

85. Heldens GTH, Blaney Davidson EN, Vitters EL, Schreurs BW, Piek E, Van Den Berg WB, et al. Catabolic factors and osteoarthritis-conditioned medium inhibit chondrogenesis of human mesenchymal stem cells. Tissue Engineering - Part A.18:45-54. 2012.

86. Felka T, Schäfer R, Schewe B, Benz K, Aicher WK. Hypoxia reduces the inhibitory effect of IL-1 $\beta$ on chondrogenic differentiation of FCS-free expanded MSC. Osteoarthritis and Cartilage.17:1368-76. 2009.

87. Majumdar MK, Wang E, Morris EA. BMP-2 and BMP-9 promote chondrogenic differentiation of human multipotential mesenchymal cells and overcome the inhibitory effect of IL-1. Journal of Cellular Physiology.189:275-84. 2001.

88. Wehling N, Palmer GD, Pilapil C, Liu F, Wells JW, Müller PE, et al. Interleukin-1 $\beta$ and tumor necrosis factor $\alpha$ inhibit chondrogenesis by human mesenchymal stem cells through NF-кB-dependent pathways. Arthritis and Rheumatism.60:801-12. 2009. 


\section{Figure Legends}

Figure 1: CFU-F assay (donor 1). Similar results were observed for all donors

Figure 2: Total number of colonies determined from CFU-F assay. (A) Donor 1 (B) Donor 2, (C) Donor 3 (D) Donor 4. $(*)$ significance compared to STD media formulation at the same oxygen concentration $(\mathrm{p}<0.05)$. (!) compared to $20 \%$ oxygen expansion condition for the same media formulation $(\mathrm{p}<0.05)$.

Figure 3: (A) Colony Diameter determined from CFU-F assay, (B) Population doubling time at the end of Passage 0 and $(\mathrm{C})$ Number of population doublings at the end of Passage $0 .\left(^{*}\right)$ significance compared to STD media formulation at the same oxygen concentration ( $p$ $<0.05$ ). (!) compared to $20 \%$ oxygen expansion condition for the same media formulation (p $<0.05)$. All donors pooled.

Figure 4: sGAG/DNA of pellets after 21 days of culture which had been expanded at $20 \%$ oxygen tension and differentitated at either $20 \%$ or $5 \%$ oxygen tension. $(*)$ significance compared to STD media formulation $(\mathrm{p}<0.001)$. (!) significance compared to the same media formulation $(\mathrm{p}<0.05)$.

Figure 5: Picro Sirius Red, Alcian Blue and type II collagen staining of pellets (day 21) expanded at $20 \% \mathrm{O}_{2}$ and differentiated at either $5 \%$ or $20 \% \mathrm{O}_{2}$.

Figure 6: (A) Total DNA and (B) sGAG/DNA content of agarose and fibrin hydrogels at day 42. * $(\mathrm{p}<0.05)$ compared to agarose hydrogel at same $\mathrm{O}_{2}$ concentration. $+(\mathrm{p}<0.05)$ compared to fibrin hydrogel at $20 \% \mathrm{O}_{2}$. 
Figure 7: (A) Stereo image of fibrin hydrogels at 20\% and 5\% oxygen $\left(\mathrm{O}_{2}\right)$ cultured in STD media or STD media $+5 \%$ FBS at day 42 . Scale bar is $5 \mathrm{~mm}(\mathrm{~B})$ Total DNA (C) sGAG \% ww and (D) sGAG/DNA at day 42. * $(\mathrm{p}<0.05)$ compared to STD at same $\mathrm{O}_{2}$ concentration. $+(p<0.05)$ com-pared to hydrogel constructs at $20 \% \mathrm{O}_{2}$.

Figure 8: Histological evaluation of agarose and fibrin hydrogels at day 42. Alcian blue staining for sulphated proteoglycan, picro sirius red for total collagen and immunohistochemical staining for collagen types I, II and X. Scale bar is $1 \mathrm{~mm}$. 


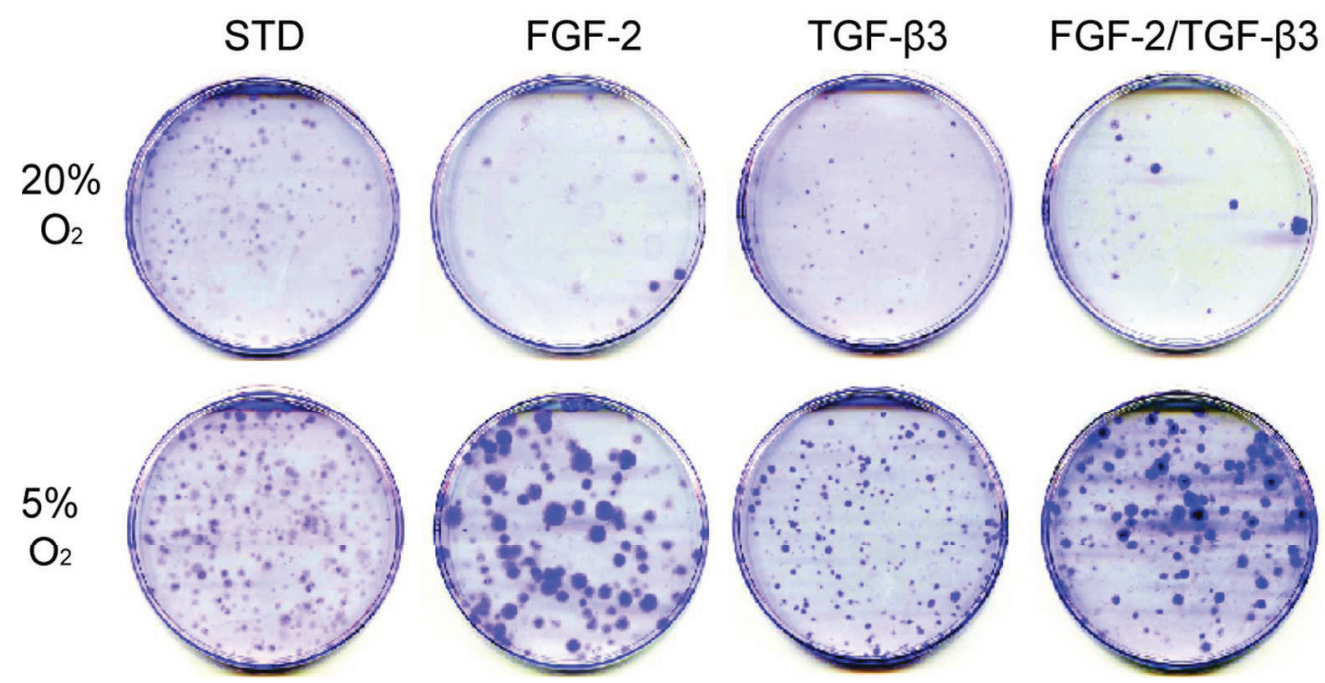

CFU-F assay (donor 1). Similar results were observed for all donors $202 \times 103 \mathrm{~mm}(150 \times 150 \mathrm{DPI})$ 


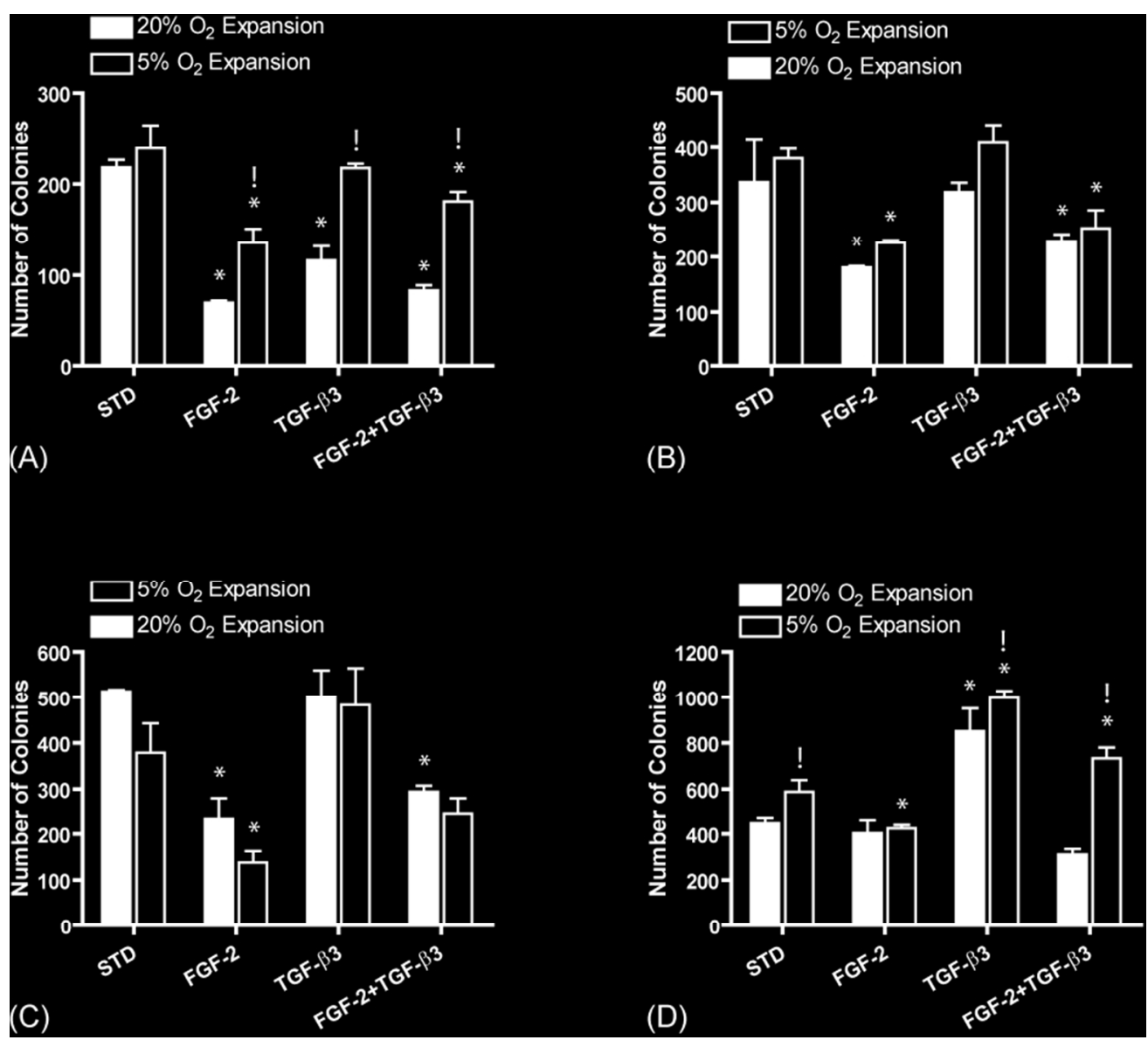

Figure 2: Total number of colonies determined from CFU-F assay. (A) Donor 1 (B) Donor 2, (C) Donor 3 (D) Donor 4. (*) significance compared to STD media formulation at the same oxygen concentration $(p<0.05)$. (!) compared to $20 \%$ oxygen expansion condition for the same media formulation $(p<0.05)$. $158 \times 142 \mathrm{~mm}(150 \times 150 \mathrm{DPI})$ 


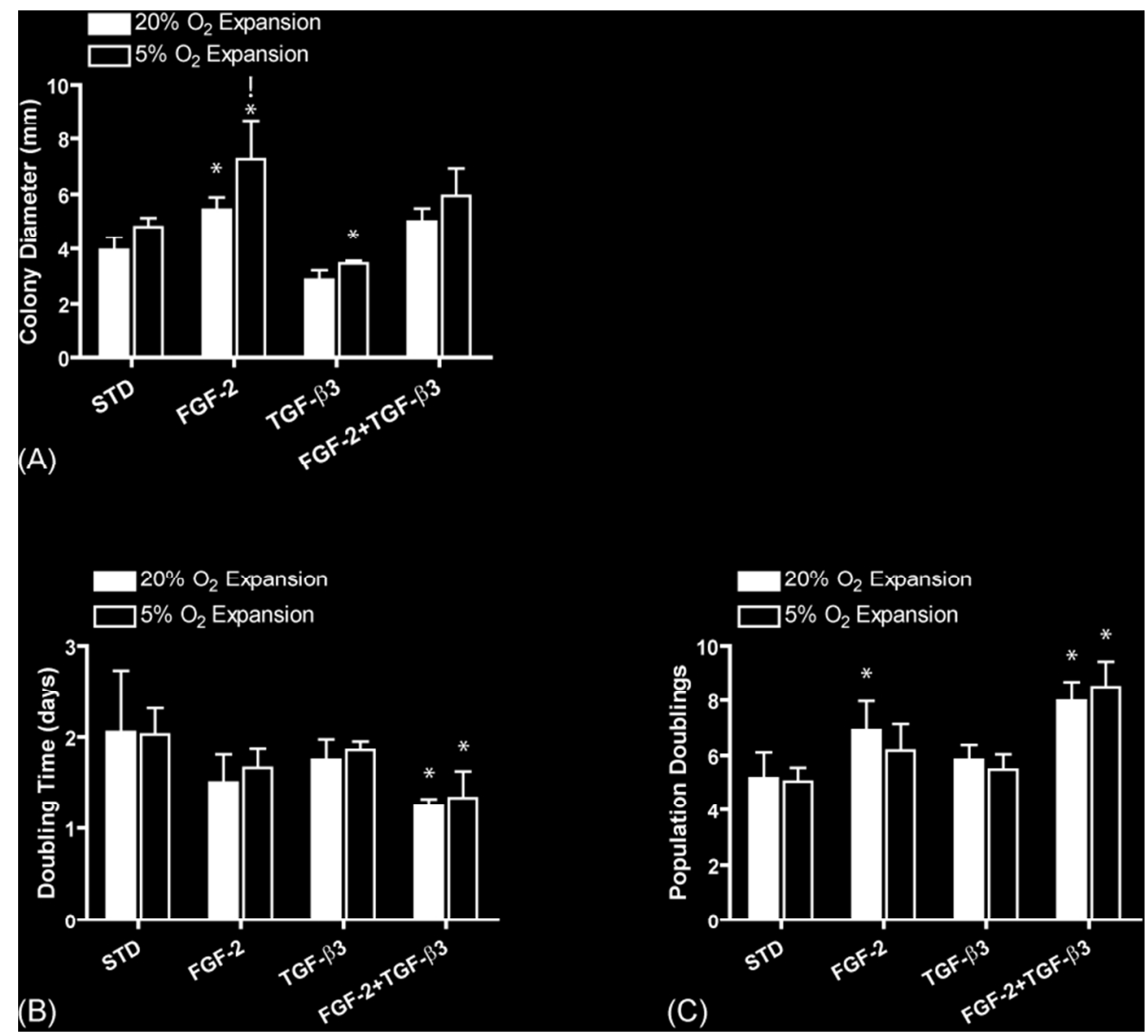

Figure 3: (A) Colony Diameter determined from CFU-F assay, (B) Population doubling time at the end of Passage 0 and $(C)$ Number of population doublings at the end of Passage 0 . (*) significance compared to STD media formulation at the same oxygen concentration $(p<0.05)$. (!) compared to $20 \%$ oxygen expansion condition for the same media formulation $(p<0.05)$. All donors pooled. $156 \times 142 \mathrm{~mm}(150 \times 150 \mathrm{DPI})$ 


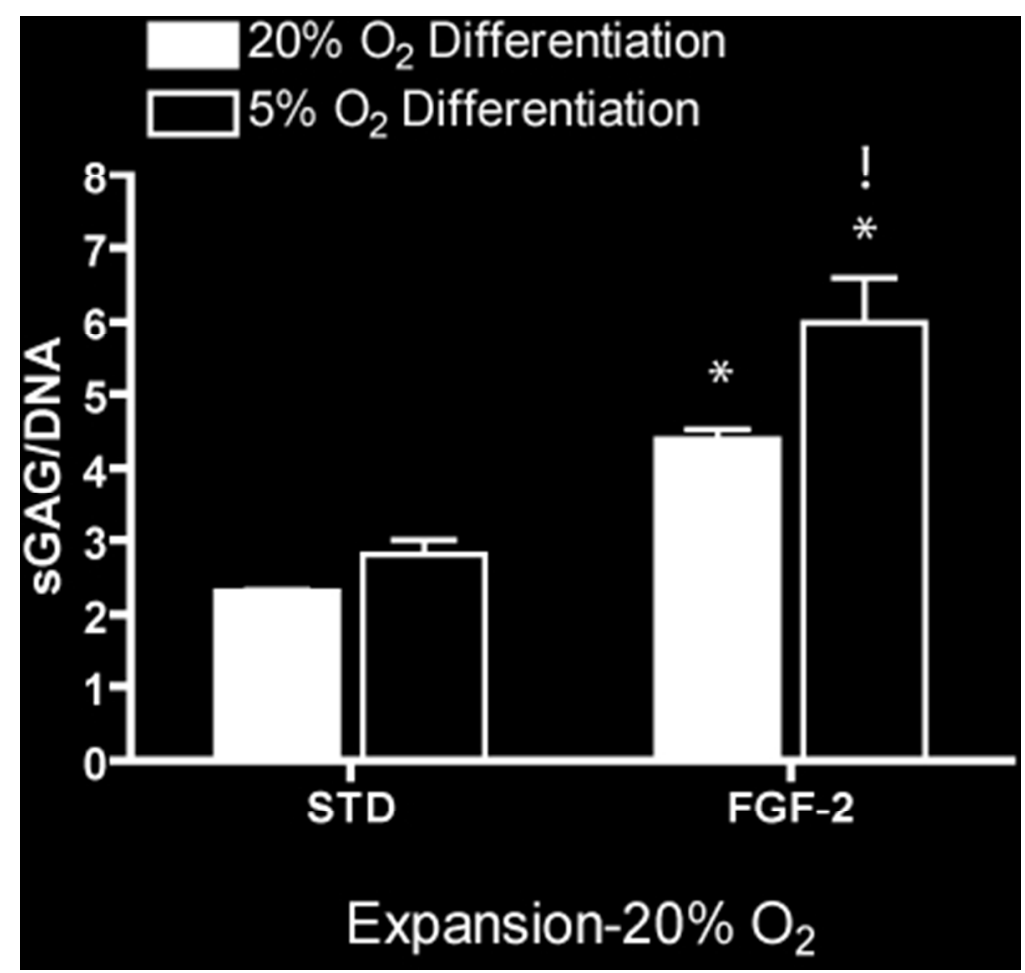

Figure 4: sGAG/DNA of pellets after 21 days of culture which had been expanded at $20 \%$ oxygen tension and differentitated at either $20 \%$ or $5 \%$ oxygen tension. $(*)$ significance compared to STD media formulation $(p<0.001)$. (!) significance compared to the same media formulation $(p<0.05)$. $65 \times 61 \mathrm{~mm}(150 \times 150 \mathrm{DPI})$ 


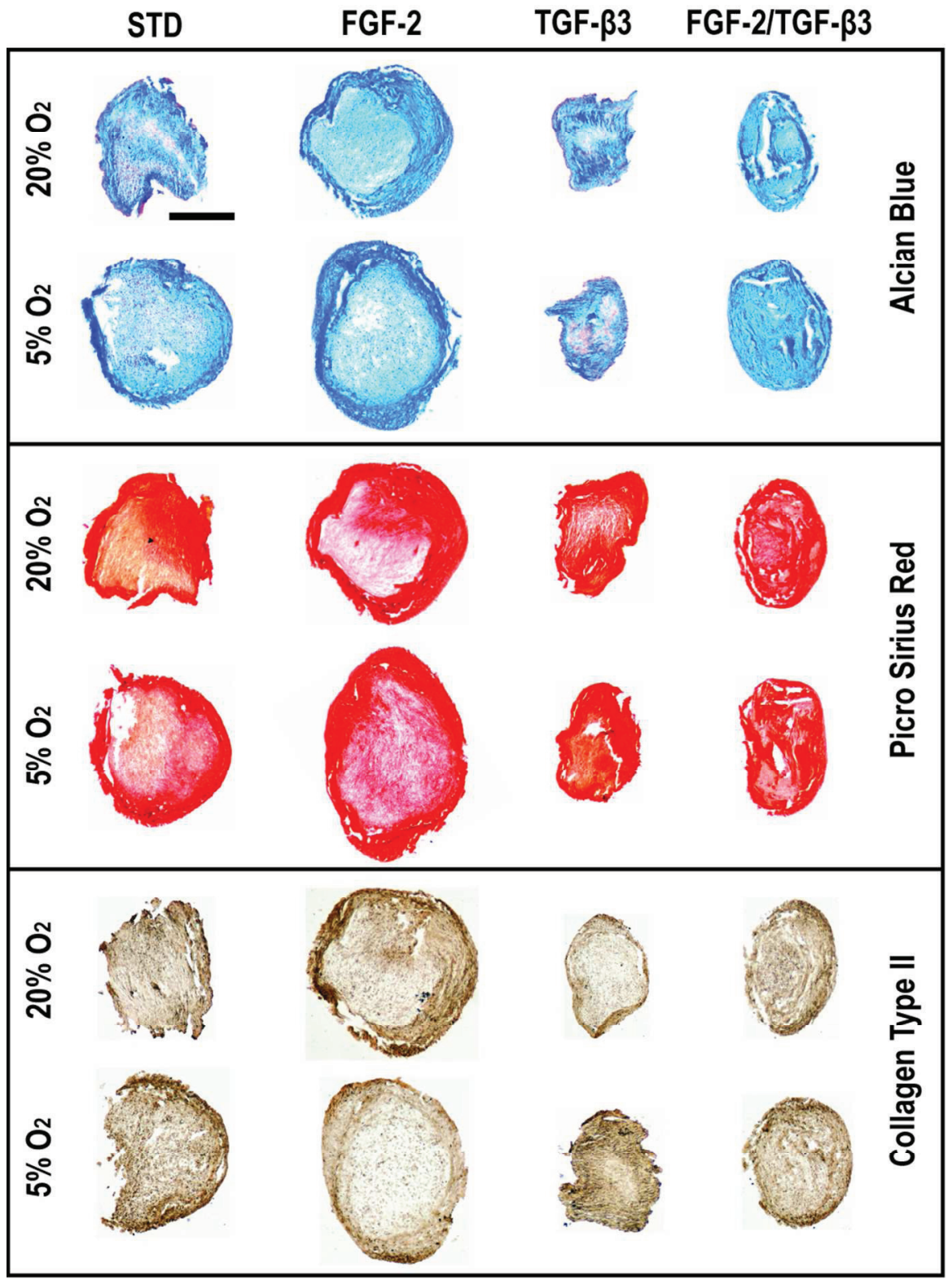

Figure 5: Picro Sirius Red, Alcian Blue and type II collagen staining of pellets (day 21) expanded at $20 \% 02$ and differentiated at either $5 \%$ or $20 \% 02$. $174 \times 236 \mathrm{~mm}(150 \times 150 \mathrm{DPI})$ 
1

2

3

4

5

6

7

8

9

10

11

12

13

14

15

16

17

18

19

20

21

22

23

24

25

26

27

28

29

30

31

32

33

34

35

36

37

38

39

40

41

42

43

44

45

46

47

48

49

50

51

52

53

54

55

56

57

58

59

60
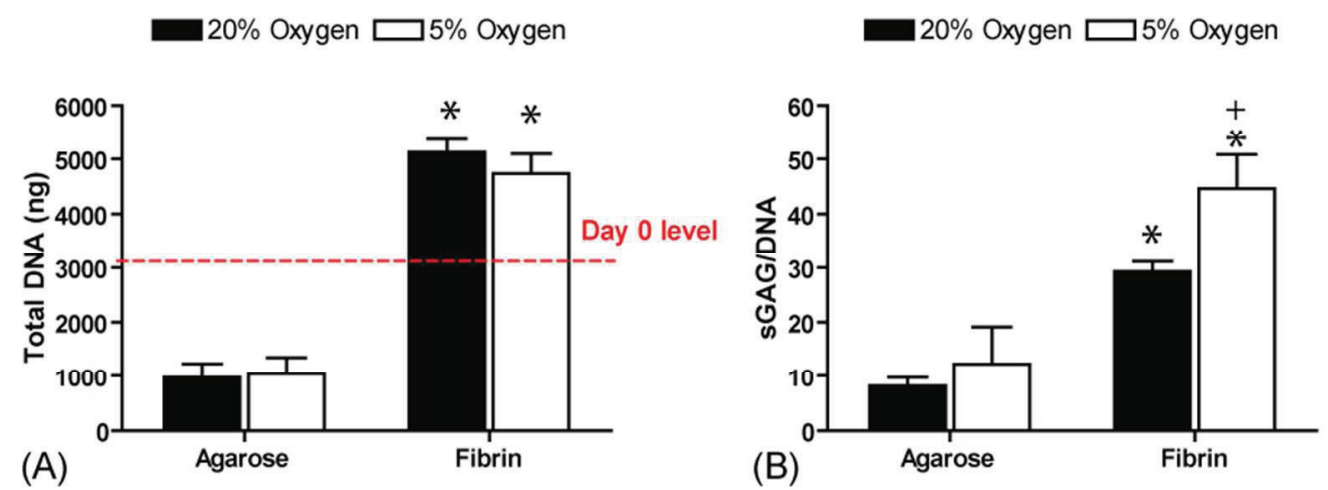

Figure 6: (A) Total DNA and (B) sGAG/DNA content of agarose and fibrin hydrogels at day $42 . *(p<0.05)$ compared to agarose hydrogel at same $\mathrm{O} 2$ concentration. $+(p<0.05)$ compared to fibrin hydrogel at $20 \%$ O2.

$152 \times 55 \mathrm{~mm}(150 \times 150 \mathrm{DPI})$ 

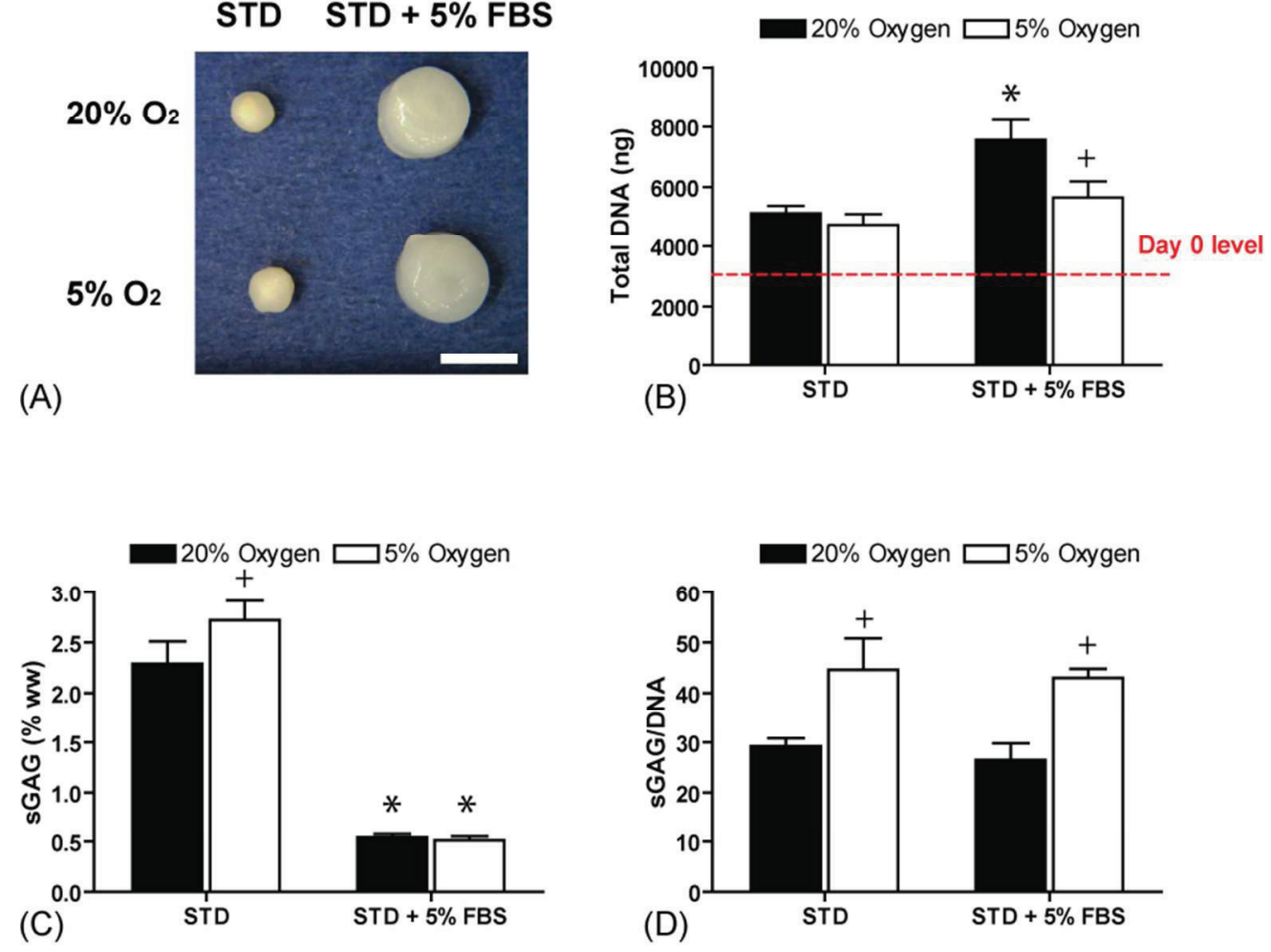

(A) STD STD + $5 \%$ FBS

\section{$5 \% \mathrm{O}_{2}$}

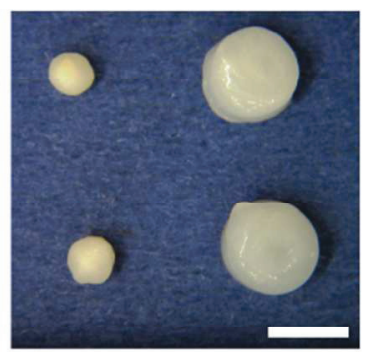

(B)

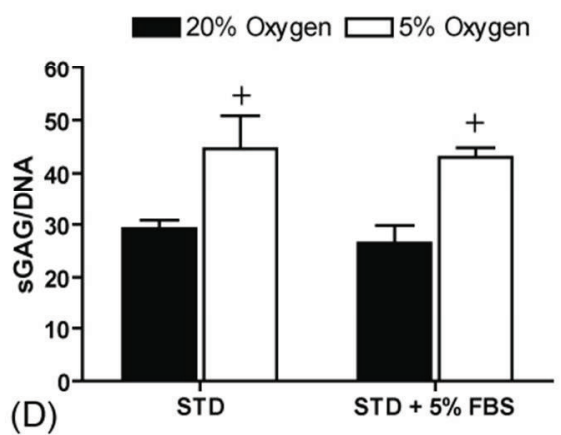

Figure 7: (A) Stereo image of fibrin hydrogels at $20 \%$ and $5 \%$ oxygen (O2) cultured in STD media or STD media $+5 \%$ FBS at day 42 . Scale bar is $5 \mathrm{~mm}$ (B) Total DNA (C) sGAG \% ww and (D) sGAG/DNA at day 42. $*(p<0.05)$ compared to STD at same 02 concentration. + $(p<0.05)$ com-pared to hydrogel constructs at $20 \% 02$. $158 \times 120 \mathrm{~mm}(150 \times 150 \mathrm{DPI})$ 


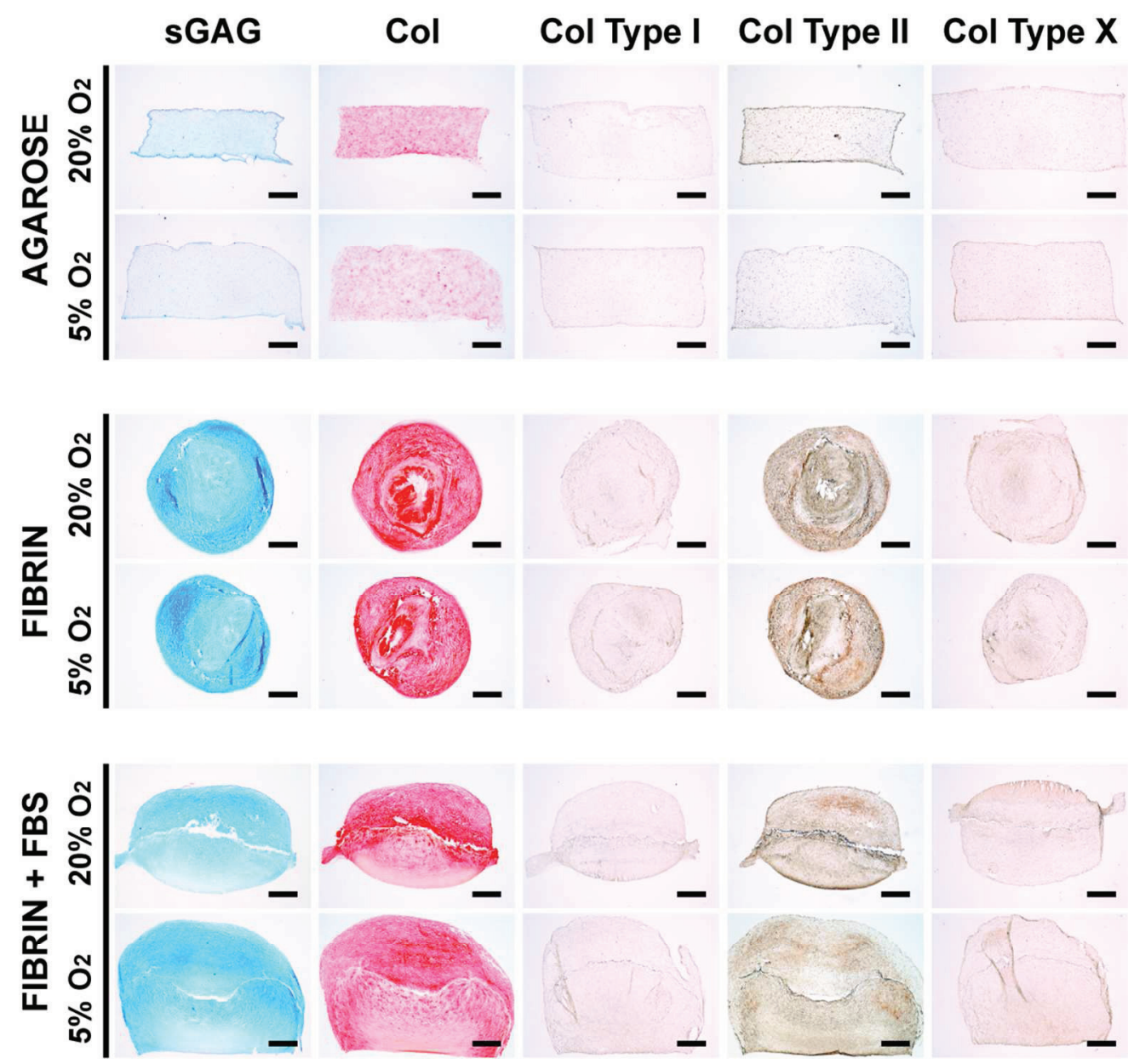

Figure 8: Histological evaluation of agarose and fibrin hydrogels at day 42 . Alcian blue staining for sulphated proteoglycan, picro sirius red for total collagen and immunohistochemical staining for collagen types I, II and $X$. Scale bar is $1 \mathrm{~mm}$. $204 \times 193 \mathrm{~mm}(150 \times 150 \mathrm{DPI})$ 